Egyptian Journal of Aquatic Biology \& Fisheries

Zoology Department, Faculty of Science,

Ain Shams University, Cairo, Egypt.

ISSN $1110-6131$

Vol. 25(5): 933 - 950 (2021)

www.ejabf.journals.ekb.eg

\title{
Effect of Aeromonas sobria infection on gills and skin histopathology of the Nile tilapia reared under biofloc and clear water systems
}

\section{Mohamed Bakr ${ }^{1}$, Shaymaa Abdelmalek ${ }^{1, *}$, Ashraf Suloma ${ }^{2}$, Mohamed A. Awad ${ }^{3}$, Saad Attia ${ }^{1}$.}

1. Department of Microbiology and Immunology, Faculty of Veterinary Medicine, Cairo University, Giza, 12211, Egypt.

2. Department of Animal Production, Fish Nutrition Lab, Faculty of Agriculture, Cairo University, Giza, 12613, Egypt.

3. Department of Cytology and Histology, Faculty of Veterinary Medicine, Cairo University, Giza, 12211, Egypt.

*Corresponding author: shaymaa_malek@cu.edu.eg

\section{ARTICLE INFO} Article History:

Received: Nov. 2, 2021

Accepted: Nov. 17, 2021

Online: Nov. 30, 2021

Keywords:

Aquaculture,

Water quality,

Heterotrophic bacteria,

Oreochromis niloticus

\section{ABSTRACT}

This study aimed to investigate the effect of $A$. sobria infection on the gills and skin histopathology of the Nile tilapia reared in biofloc technology (BFT) compared to a clear water system (CWS). The Nile tilapia fish were divided into four groups: two groups in BFT (control group without infection (BFTC) and $A$. sobria infected group (BFTT)) and the other two in CWS (control group without infection (CWSC) and A. sobria infected group (CWST)). The infection was done by I/P (intraperitoneal) injection of $0.1 \mathrm{ml}$ of $1.5 \times 10^{8} \mathrm{CFU} / \mathrm{ml}$ of $A$. sobria. The gills histopathology of CWST group showed moderate to severe histopathological alterations; congestion of lamellar blood vessels, mononuclear and eosinophilic leukocytic infiltration, and sloughing of lamellar epithelium; while it only showed mild epithelial hyperplasia in the BFTT group. Skin hyperemia and tail rot were observed grossly without any histopathological alterations in the skin of both BFTT and CWST groups. Total heterotrophic bacterial count in the culture water was higher in BFTC group, nevertheless, its count in fish gut was higher in CWSC group. In both BFTT and CWST groups, after infection, a decrease was detected in the total heterotrophic bacterial count in the culture water and fish gut, while it was still higher in BFTT group. At the early stage of $A$. sobria infection, the gills were severely affected, and its injury may not be observed, paving the way for other diseases. Meanwhile, the skin may show hyperemia grossly without any histopathological alterations. Results of the current study showed that the biofloc system proved its capacity of protecting the gills of the Nile tilapia against $A$. sobria infection.

\section{INTRODUCTION}

The aquaculture intensification and expansion are required due to the increasing demand on sea food (Mastan, 2015). The aquaculture intensification may cause water quality deterioration, which, in turn, may increase disease spread, leading to economic 
losses (Bondad-Reantaso et al., 2005). This aquaculture intensification can be done through many systems as clear water system (RAS) and biofloc system (BFT). BFT is a highly sustainable system as biofloc bacteria can maintain water quality by conversion of nitrogenous wastes into nitrate via nitrification process or its assimilation (Avnimelech, 2012; El-Shafiey et al., 2018; Mabroke et al., 2019). In addition, bioflocs act as an additional source of nutrition for reared organisms, among which is the Nile tilapia and help in decreasing feed conversion rates (Azim \& Little, 2008; Hargreaves, 2013).

The Nile tilapia shares with $8.3 \%$ of the finfish aquaculture production, occupying the third place after grass and silver carps with respect to the most cultivable species (FAO, 2020). The Nile tilapia is considered an ideal fish candidate for BFT due to its grazing, filter-feeding and detritivory habits aligned with its capacity to resist poor water quality and high concentration of solids in water (Avnimelech, 2009; Hargreaves, 2013).

Bacterial infection is more prevalent in coastal and inland aquaculture facilities than in open seas (World Health Organization, 1999), particularly Streptococcus spp. and Aeromonas spp. They are the main cause of bacterial diseases affecting the tilapia and can cause large economic losses, especially in overwintering stage of the tilapia production (Li \& Cai, 2011). Thus, maximizing disease resistance and culture performance is the main challenge facing aquaculture (Trust, 1986).

Aeromonas spp. are gram negative, motile and short rods that are normal inhabitant of fish gut and aquatic environment, and under abnormal conditions, it can cause disease and mortality within 1 week of infection (Monfort \& Baleux, 1990; Yu et al., 2010). Diseased fish is recognized with skin lesions, fin erosions, eye infection, and hemorrhagic septicemia (Noga, 2010). Motile Aeromonas Septicemia (MAS) is caused by motile aeromonads, which are biochemically differentiated isolates, including Aeromonas hydrophila, Aeromonas caviae and A. sobria (Toranzo et al., 1989; Austin et al., 2007). Moustafa et al. (2020) mentioned that, Aeromonas infection is the most serious obstacle that prevents the global expansion of the Nile tilapia industry.

A. sobria is a common bacterial water inhabitant that can produce an acute or chronic infection to the tilapia via its virulence factors such as enterotoxins, hemolysin and others (Kozińska, 2007; Ibrahim et al., 2021). A. sobria can cause hemorrhagic septicemia all over the year, particularly during poor water quality, less water change, high stocking density, overwintering and unstable temperature (Cai et al., 2004). Li and Cai, (2011) found that $A$. sobria can cause tail rot disease for the juvenile tilapia. Dar et al. (2016) found that $A$. sobria was associated with skin and gills lesions in silver carp.

It is overall accepted that prevention of infectious diseases is a more preferred strategy compared to disease treatment because of the high cost and the increased regulation on the use of chemicals for safety issues (Ajadi et al., 2016). Misuse of antibiotics may lead to antibiotic resistant bacterial strains and antibiotics residues in fish meat (Weston, 1996; Cabello, 2006). Consequently, there is an urgent need to use 
antibiotic replacers as prebiotics, probiotics, symbiotics, and other microbial based biocontrol agents (Ajadi et al., 2016; El-Naggar et al., 2021). BFT has a probiotic effect because of its competitive exclusion for pathogenic microbes and may also enhance the activity of digestive enzymes in fish (Emerenciano et al., 2013; Kim et al., 2014). Robles-Porchas et al. (2020) mentioned that BFT has a good effect on the antioxidant capacity and the immunity of fish.

There is no available data about the protective capacity of BFT heterotrophic bacteria against $A$. sobria challenge in the Nile tilapia. Therefore, the aim of the present study was to evaluate the effect of A. sobria challenge on gills and skin histopathology of the Nile tilapia reared under biofloc system conditions compared to clear water system.

\section{MATERIALS AND METHODS}

\section{Ethical statement}

The experimental protocol and ethics were done following the recommendations of the institutional animal care and use committee (IACUC) of the Faculty of Veterinary Medicine, Cairo University, and was approved by the faculty ethics committee (Approval No. Vet CU 12/10/2021/354).

\section{Experimental conditions and location}

Around 132 Nile tilapia fish $(85.6 \pm 0.29$ grams as mean \pm SE) were transported from a farm located in kafr el-Sheikh to fish nutrition laboratory at The Faculty of Agriculture, Cairo university. Fish were put in $3 \mathrm{~m}^{3}$ tank with salinity 2 ppt. After 2 weeks, these fish were distributed randomly into twelve 55-L plastic tanks. These tanks were previously disinfected by chlorine and potassium permanganate. The fish were acclimated in these tanks for 1 month before infection, and during this period, water quality was weekly monitored.

\section{Experimental design}

Nile tilapia fish were divided into four groups: two groups in BFT (control group without infection (BFTC) and A. sobria infected group (BFTT)) and the other two in CWS (control group without infection (CWSC) and A. sobria infected group (CWST)). The biofloc system was constructed by an addition of 20 liters from mature biofloc tank in each tank as biofloc inoculum. The corn starch, forming a carbon source, was added to the biofloc groups according to Samocha (2019) and no water was exchanged; just compensation of water evaporation. While, in CWS groups, water was exchanged twice/week by $100 \%$. The fish were fed at a daily ration of $1 \%$ of its body weight. After A. sobria infection, no feed was introduced to fish.

\section{Aeromonas sobria infection}

A. sobria strain was obtained from AHRI (Animal Health Research Institute, Department of Microbiology), confirmed by plating into MacConkey agar (Hi media, India) according to Dong et al. (2015), gram staining and biochemical identification 
(oxidase, catalase, urease, citrate, indole, and TSI). Finally, this strain was confirmed by Vitek-2 compact (bioMérieux, France) using gram negative identification card (Elbehiry et al., 2019). Two fish per tank were collected to confirm freedom of $A$. sobria by direct streaking from kidney, liver, spleen, and gills on MacConkey agar (Hi media, India), and using of gram staining and biochemical testing (oxidase, catalase, citrate, urease, and TSI). After the acclimation period, the infection was done by I/P injection of both BFTT and CWST groups by $0.1 \mathrm{ml}$ of $1.5 \times 10^{8} \mathrm{CFU} / \mathrm{ml}$ of $A$. sobria strain according to Reda $\boldsymbol{e t}$ al. (2016), while both BFTC and CWSC groups were I/P injected by $0.1 \mathrm{ml}$ saline. The infection was confirmed by re-isolation of A. sobria from internal organs, especially kidneys, using MacConkey agar (Hi media, India) and confirmed by gram staining and biochemical tests (oxidase, catalase, citrate, urease and TSI). The results of biochemical tests were interpreted according to Abbott et al. (2003).

\section{Total heterotrophic bacterial count}

Fifteen $\mathrm{ml}$ of culture water were collected from each tank, and five cm length of both anterior and posterior gut were collected into $5 \mathrm{ml}$ saline. Total bacterial count was done by pooling water/gut samples together for the same group before and after infection. Ten-fold serial dilution was performed for each pooled sample and $100 \mu$ of each dilution $\left(10^{-1}\right.$ to $\left.10^{-5}\right)$ was inoculated on plate count agar (Hi media, India) by spreading method into duplicates and incubated at $37^{\circ} \mathrm{C}$ for 24 hours according to Ferreira et al. (2017) and Stahlke et al. (2018). The plates ranged from (30-300) colonies and were counted manually according to Sutton Scott (2011).

\section{Histopathology}

The specimens (skin and gills) were collected, fixed in 10\% neutral buffered formalin $(10 \% \mathrm{NBF})$, washed, dehydrated, cleared, and embedded in paraffin blocks. Then, they were sectioned (4 $\mu \mathrm{m}$ thickness) using microtome (Leica, Germany) for hematoxylin and eosin (H\&E) staining (Bancroft \& Gamble, 2008). The stained slides were viewed using the light microscope (LEICA DM500) under x200 \& x400 magnification, then images were captured with (LEICA ICC50 HD) a camera attached to the microscope and finally examined and analyzed by image analysis software (Leica microsystems (LAS version 3.8.0 [ build:878 ] Leica Ltd) image analyzer computer system. The histopathological alterations were scored and graded, where $(<30 \%)$ showed mild, (30:50\%) showed moderate, while ( $>50 \%)$ indicated severe alterations.

\section{Water quality measurement}

Physicochemical water quality parameters of both BFTC and CWSC groups were monitored every week at three sampling dates during the acclimation period as follows: dissolved oxygen and water temperature were measured using SensoDirect Oxi 200 device, and the $\mathrm{pH}$ was detected using Milwaukee-PH600 Digital pH meter tester pocket Pen. Total ammonia nitrogen (TAN) values and nitrite (NO2-N) were determined using water analysis photometer (MultiDirect Lovibond). Alkalinity was monitored by titration against sulfuric acid till $\mathrm{pH}$ point of 4.5 (APHA, 1998). Floc level was determined by 
sedimentation of flocs on the bottom of Imhoff cones for 15 minutes (Avnimelech, 2009). Total suspended solids (TSS) were measured by water analysis photometer (MultiDirect Lovibond), whereas the salinity was assessed using digital salinometer (Adwa AD32 EC/TDS).

\section{Statistical analysis}

The statistical analysis of water quality results of both BFTC and CWSC groups was achieved using independent samples $t$-test via SPSS (version,28), and the results were recorded as significant when $P$. value was less than 0.05 . The other results were reported as mean \pm SE using SPSS (version,28).

\section{RESULTS}

\section{Aeromonas sobria infection}

Characters of Aeromonas sobria are shown in Fig. (1). On MacConkey agar (Hi media, India), A. sobria produced non-lactose fermenter colonies, and gram's stain showed gram negative short rods. Biochemically, this strain was K/A (Alkaline/Acid) on TSI, positive for oxidase, catalase, citrate, and indole tests and negative for urease test. Finally, the result of Vitek-2 compact confirmed the strain as A. sobria with excellent identification. All randomly selected fish were found free from A. sobria because the cultural and biochemical characters of isolated colonies didn't meet the characters of $A$. sobria. After infection, some fish showed skin hyperemia, congested and necrotic gills and tail rot as shown in Fig. (2).

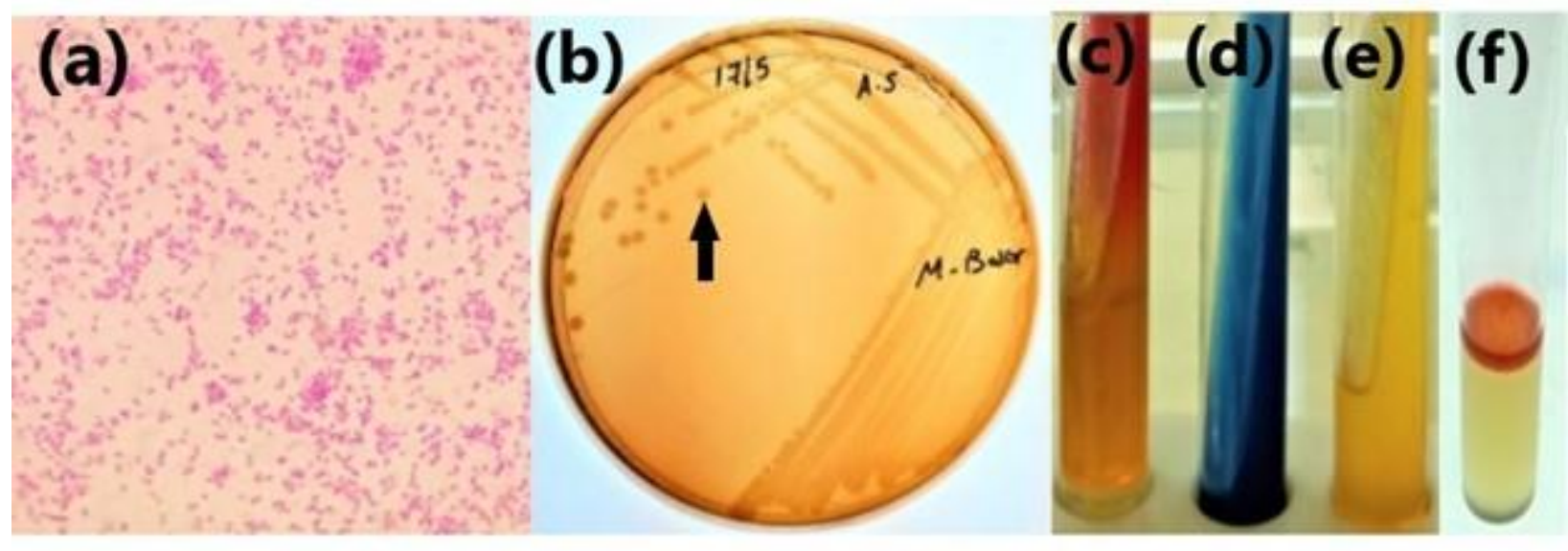

Fig. 1. Characters of A. sobria (a) Gram negative short rods stained by gram's stain. (b) Non-lactose fermenter colonies (arrow) on MacConkey agar. (c) TSI: K/A. (d) Citrate: +ve. (e) Urease -ve. (f) Indole: +ve. 


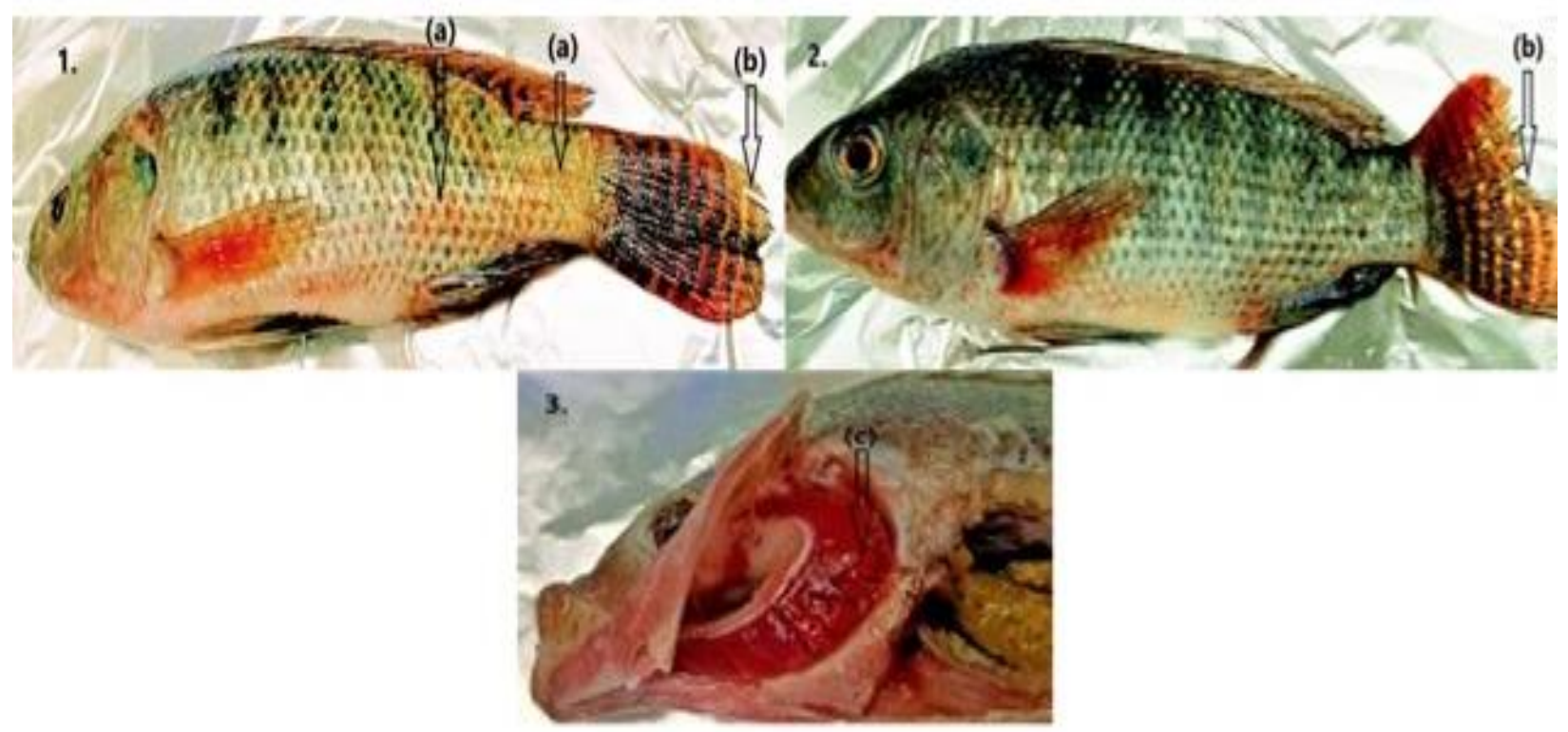

Fig. 2. A. sobria infected Nile tilapia showing: 1. Skin hyperemia (a) and tail rot (b). 2. tail rot (b). 3. Congested and necrotic gills (c).

\section{Histopathology}

Histopathological assessment of skin and gills are shown in Figs. (3,4, and Table 1). No skin histopathological alterations were noticed in the infected groups compared to the control groups. Normal histological appearance of gills was found in the control groups (BFTC and CWSC). On the other hand, gills of fish infected by A. sobria under clear water conditions showed congestion of lamellar blood vessels, mononuclear and eosinophilic leukocytic infiltration, and sloughing of lamellar epithelium. The severity of these histological alterations was less in fish infected by A. sobria under biofloc conditions, and merely showing epithelial hyperplasia.

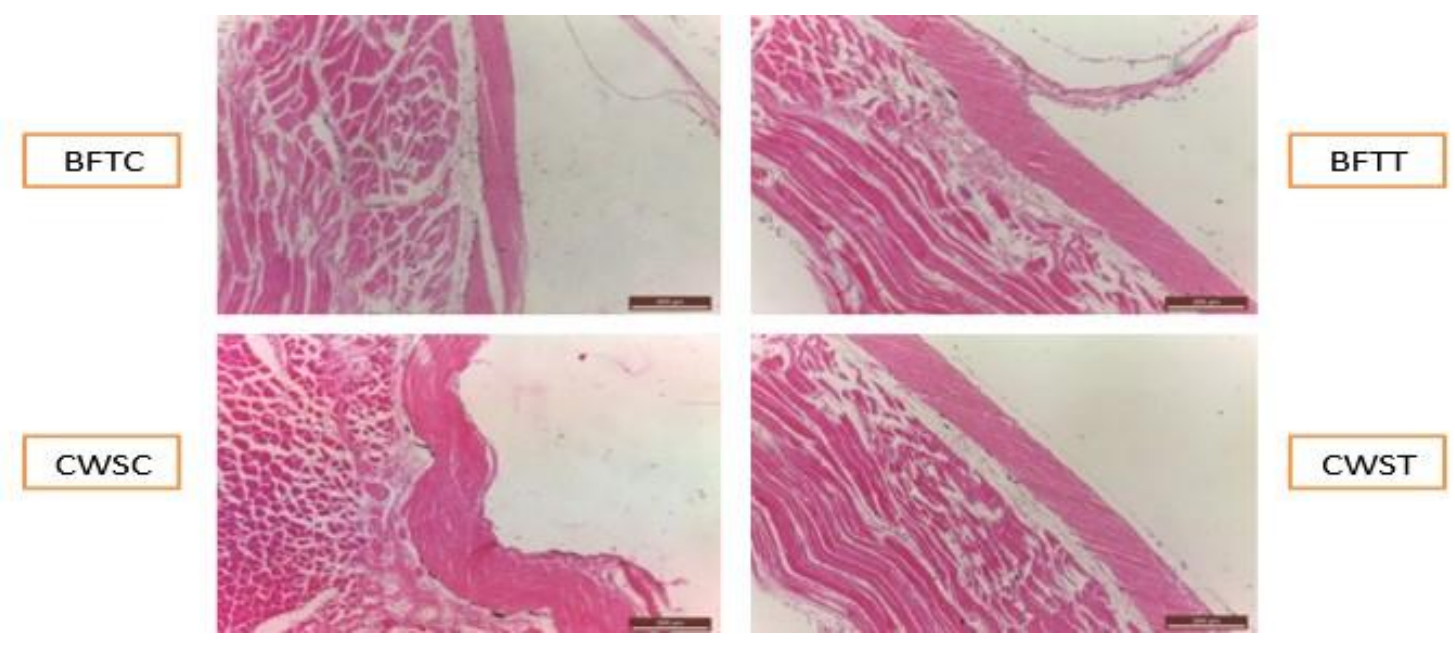

Fig. 3. Photomicrographs of fish skin showing no histopathological alterations in all groups (H\&E, skin; 4X, scale bar $200 \mathrm{~mm}$ ) 


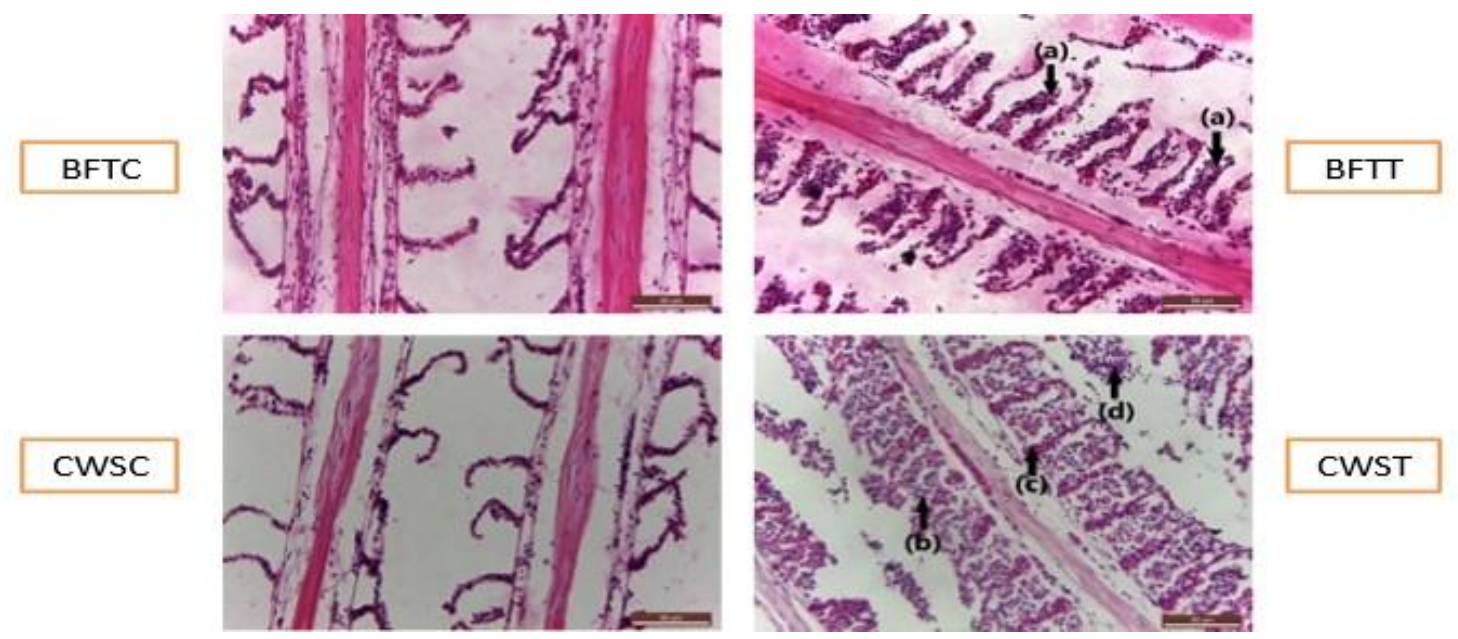

Fig. 4. Photomicrographs of fish gills showing epithelial hyperplasia (a) in BFTT group. Mononuclear and eosinophilic infiltration (b), Congestion of lamellar blood vessels (c), and sloughing of lamellar epithelium (d) in CWST group (H\&E, gills; 40X, scale bar).

Table 1. Histological assessment of gills in all treatments

\begin{tabular}{c|c|c|c|c|}
\hline Histopathological alterations & BFTC & BFTT & Nil & Moderate \\
\hline Congestion of lamellar blood vessels & Nil & Mild & Nil & Moderate \\
\hline Mononuclear and eosinophilic infiltration & Nil & Mild & Nil & Severe \\
\hline sloughing of lamellar epithelium & Nil & Mild & Nil & Nil \\
\hline epithelial hyperplasia & Mild & Moderate & & \\
\hline
\end{tabular}

Lesion score: 0 NIL; 1 Mild; 2 Moderate; 3 Severe. BFTC: control biofloc group; BFTT: A. sobria infected biofloc group; CWSC: control CWS group; CWST: A. sobria infected biofloc group.

\section{Total heterotrophic bacterial count}

The results of the total heterotrophic bacterial count in culture water and fish gut are presented in Table (2). The total heterotrophic bacterial count in culture water was higher in BFTC group. While, the total heterotrophic bacterial count in fish gut was higher in CWSC group. After infection, the total heterotrophic bacterial count in culture water and fish gut decreased in both BFTT and CWST groups, but it was still higher in BFTT group. 
Table 2. The results of total heterotrophic bacterial count in all treatments (values are mean \pm SE)

\begin{tabular}{c|c|c|c|c}
\hline \multicolumn{1}{c}{ Parameter } & BFTC & BFTT & CWSC & CWST \\
\hline $\begin{array}{c}\text { Total heterotrophic bacterial count } \\
\text { in culture water } \times 10^{5}(\mathrm{CFU} / \mathrm{ml})\end{array}$ & $158 \pm 88$ & $18.6 \pm 0.5$ & $0.45 \pm 0.05$ & $0.243 \pm 0.057$ \\
\hline $\begin{array}{c}\text { Total heterotrophic bacterial count } \\
\text { in fish gut } \times 10^{6}(\mathrm{CFU} / \mathrm{ml})\end{array}$ & $283 \pm 32$ & $16.8 \pm 2.2$ & $295 \pm 25$ & $14.8 \pm 0.2$ \\
\hline
\end{tabular}

BFTC: control biofloc group; BFTT: A. sobria infected biofloc group; CWSC: control CWS group; CWST:

A. sobria infected biofloc group.

\section{Water quality}

The results of water quality under control biofloc and clear water conditions are presented in Table (3). Those results didn't show significant difference in water temperature, dissolved oxygen, salinity, or ammonia level between BFTC group and CWSC group. Significant increase of nitrite level was recorded in BFTC group compared to CWSC group. On the other hand, significant decreases of $\mathrm{pH}$ and alkalinity were recorded in BFTC group compared to CWSC group. The TSS and floc level in BFTC group were $117.05 \pm 14.67 \mathrm{mg} / \mathrm{l}$ and $6.48 \pm 1.01 \mathrm{mg} / \mathrm{l}$, respectively.

Table 3. The values of water quality parameters monitored during acclimation period in 3 sampling dates in both BFTC and CWSC groups (values are mean \pm SE)

\begin{tabular}{l|c|c|c|}
\hline \multicolumn{1}{c}{ Water quality parameter } & BFTC & CWSC & P. value \\
\hline Water temperature $\left({ }^{\circ} \mathrm{C}\right)$ & $27.66 \pm 0.19$ & $27.79 \pm 0.24$ & 0.192 \\
\hline Dissolved oxygen $(\mathrm{mg} / \mathrm{l})$ & $4.97 \pm 0.06$ & $5.1 \pm 0.07$ & 0.227 \\
\hline Salinity $(\mathrm{ppt})$ & $1.96 \pm 0.02$ & $2.13 \pm 0.01$ & 0.381 \\
\hline $\mathrm{pH}$ & $8.62 \pm 0.03$ & $8.78 \pm 0.19^{*}$ & 0.017 \\
\hline Ammonia $(\mathrm{mg} / \mathrm{l})$ & $0.28 \pm 0.06$ & $0.41 \pm 0.1$ & 0.58 \\
\hline Nitrite $(\mathrm{mg} / \mathrm{l})$ & $0.3 \pm 0.02^{* * * *}$ & $0.04 \pm 0.01$ & 0.001 \\
\hline Alkalinity $(\mathrm{mg} \mathrm{CaCO} / \mathrm{l})$ & $301.01 \pm 15.32$ & $331.62 \pm 6.73^{*}$ & 0.044 \\
\hline Floc level $(\mathrm{mg} / \mathrm{l})$ & $6.48 \pm 1.01$ & - & - \\
\hline TSS $(\mathrm{mg} / \mathrm{l})$ & $117.05 \pm 14.67$ & - & - \\
\hline Data & & - & \\
\hline
\end{tabular}

Data were analyzed by independent sample t-test to compare between 2 groups $\left({ }^{*} \mathrm{p}<0.05 ;{ }^{* * *} \mathrm{p} \leq 0.001\right)$. BFTC: control biofloc group; CWSC: control CWS group. TSS: total suspended solids.

\section{DISCUSSION}

A few studies investigated the infectious disease resistance of fish reared under biofloc system and the results were very promising (Ekasari et al. 2014; Ahmed et al. 2016). Bakhshi et al. (2018) reported that biofloc system can increase disease resistance of carp fingerlings against Aeromonas hydrophila due to its positive effects on immune response, antioxidant capacity, and hematological parameters. 
Histopathology is commonly used to investigate pathological changes caused by different chemicals or microbial pathogens as biomarkers (Camargo \& Martinez 2007; Forouhar Vajargah et al. 2018). Jia et al. (2017) reported that normal gills is formed of rows of filaments based on cartilaginous arch. In the present study, normal gills in both BFTC and CWSC groups were noticed. Morrison et al. (2007) reported that normal skin is consisted of two layers; an outer one (epidermis), which is formed of outer squamous and cuboidal cells as well as inner basal germinal cells, and an inner one (dermis), which is formed of an outer layer of stratum spongiosum (cellular layer) followed by stratum compactum (non-cellular layer). In the present study, normal skin tissue in both BFTC and CWSC groups were observed. The results of the present study are in agreement with those of Najdegerami et al. (2017), Romano et al. (2018) and Haghparast et al. (2020) who reported that, the BFT system did not harm skin, gills, or internal organs of fish. Moreover, the mild histopathological changes in gills (epithelial hyperplasia) were noticed in BFTC group. This finding agrees with that in the study of Angeles-Escobar et al. (2021) who reported that, gill epithelium may show mild to severe hyperplasia, lamellar congestion and partial or complete lamellar fusion in red pacu fish reared in biofloc system due to excessive suspended solids.

The current histopathological examination revealed that, the Nile tilapia gills in BFTT group showed mild histopathological alterations (epithelial hyperplasia). Whereas, the Nile tilapia gills in CWST group showed moderate to severe histopathological alterations (congestion of lamellar blood vessels, mononuclear and eosinophilic leukocytic infiltration, and sloughing of lamellar epithelium). This result concurs with that of El Deen et al. (2014) who reported similar histopathological alterations in the gills of the Nile tilapia infected by Aeromonas spp. Similarly, Dar et al. (2016) reported that A. sobria can cause lamellar hyperplasia, degenerative changes, and acute hemorrhages of gill epithelium in silver carp. Thus, it can be concluded that, the biofloc system can protect the gills of the Nile tilapia against severe histopathological changes caused by A. sobria. The present results coincide with those of Menaga et al. (2019) who noted that, the BFT showed mild pathological alterations on gut, kidney and liver in comparison with the control group, when the tilapia were infected by Aeromonas hydrophila. Sakai (1999) and Abraham et al. (2007) attributed the protective capacity of biofloc system to immunostimulatory compounds produced by biofloc heterotrophic bacteria. Infected groups showed skin hyperemia, while histopathological examination of skin revealed normal skin histology. This result indicates that skin may show hyperemia grossly without any histopathological alterations. The current finding agrees with that of Yildirim et al. (2006) who reported that, no significant histopathological alterations were noticed in the skin of the tilapia exposed to deltamethrin toxicity, while skin hemorrhage was observed grossly. This result disagrees with the finding of El Deen et al. (2014) who reported that, Aeromonas hydrophila could cause skin ulcers for the Nile tilapia, suggesting that $A$. hydrophila is more virulent than A. sobria. The gills are severely 
affected in the early stage of $A$. sobria infection, and its injury may not be observed, paving the way for other diseases. Infected fish showed tail rot in both BFTT and CWST groups. This observationmatches with that of Li and Cai (2011) who noticed that, $A$. sobria was associated with tail rot disease in juvenile Nile tilapia.

In the present study, the total heterotrophic bacterial count in culture water was higher in BFTC group. This result is in agreement with the finding of Haghparast et al. (2020) and Kishawy et al. (2020) who reported that, the total bacterial count of water in biofloc system was higher compared to the control group (CWS). It is assumed that, the microbial richness in culture water of BFT is higher compared to that of the CWS; an assumption of which may explain the probiotic capacity of the BFT system. The total heterotrophic bacterial count in fish gut, in both BFTC and CWSC groups, were $283 \pm$ $32 \times 10^{6} \mathrm{CFU} / \mathrm{ml}$ and $295 \pm 25 \times 10^{6} \mathrm{CFU} / \mathrm{ml}$, respectively. This result agrees with that of Kim et al. (2007) who noticed that, the total bacterial count in fish gut ranged from $10^{6}$ to $10^{8} \mathrm{CFU} / \mathrm{gm}$. The total heterotrophic bacterial count in fish gut was higher in CWSC group, which indicates that fish gut in CWS can maintain its bacterial population despite of the low bacterial count in culture water. Conversely, Kishawy et al. (2020) reported that, the intestinal bacterial count in the Nile tilapia was higher in BFT than CWS. Total heterotrophic bacterial count in fish gut in both BFT and CWS groups was higher than its count in culture water. This result disagrees with Pérez-Fuentes et al. (2018) who reported that, water bacterial load was higher than that isolated from gut contents in biofloc system. No previous studies investigated the effect of A. sobria infection on the total heterotrophic bacterial count in culture water and the gut of the Nile tilapia reared under BFT and CWS conditions. The present study reported that the total heterotrophic bacterial count in culture water and fish gut decreased in both BFTT and CWST groups; a decline that may indicate the heterotrophic bacterial competition against A. sobria. Conversely, the total heterotrophic bacterial count in culture water and gut were still higher in BFTT group than CWST group, which may indicate strong ability of biofloc heterotrophic bacteria to compete A. sobria pathogen. This result could be explained by Emerenciano et al. (2013) who reported that biofloc bacteria and its products have similar action of organic acids, reducing the $\mathrm{pH}$ of gut content which inhibits the growth of pathogenic microorganisms, increasing the replication of beneficial bacteria and improving gut immunity. Thus, it is worthy to note that, this point needs further studies to evaluate the changes of the microbial community structure of culture water and fish gut against A. sobria infection using metagenomic tools as metagenomic $16 \mathrm{~S} r$ RNA amplicon analysis.

All physicochemical water quality parameters in both BFTC group and CWSC group were reported within the normal ranges for theNile tilapia rearing according to Hepher and Pruginin (1981), Boyd (1982), Chen (1988), Lawson (1995) and Boyd (1998). These results indicate that the biofloc system can maintain water quality without water exchange, providing water resources as a sustainable system. No significant 
difference was reported in water temperature, salinity, or dissolved oxygen between BFTC group and CWSC group. Contrarily, Fleckenstein et al. (2018) reported that the dissolved oxygen was significantly lower in BFT than in CWS due to the microbial oxygen consumption in BFT. The $\mathrm{pH}$ was significantly lower in BFTC group than in CWSC group. Boyd and Tucker (2014) related that finding to the high oxygen consumption of biofloc microbes and $\mathrm{CO} 2$ release, causing lower $\mathrm{pH}$ levels via the production of carbonic acid. All measured ammonia levels $\left(\mathrm{TAN}^{-1}\right)$ were found within the normal ranges for fish rearing (less than $1 \mathrm{mg} / \mathrm{l}$ ) according to Chen (1988). No significant difference was reported in ammonia level between BFT C group and CWS C group. This result disagrees with those of Ray et al. (2017) and Fleckenstein et al. (2018) who reported that the ammonia level was significantly higher in CWS than BFT. Nitrite levels (NO2-N) were reported within the normal range for the Nile tilapia farming (less than 1 $\mathrm{mg} / \mathrm{l}$ ) according to Emerenciano et al. (2017). Nitrite nitrogen level was significantly higher in BFTC group compared to the CWSC group. This result agrees with the studies of Azim and Little (2008), Ray et al. (2011) and Ray et al. (2017) who reported that, the high nitrite level is the most common problem associated with BFT. Hargreaves (1998) attributed the afore- mentioned observation to the fact that ammonia conversion rate is done in a faster manner in biofloc than CWS via BFT heterotrophic bacteria. Alkalinity levels in both BFTC and CWSC groups were (301.01 $\left.\pm 15.32 \mathrm{mg} \mathrm{CaCO}_{3} / \mathrm{l}\right)$ and (331.62 $\pm 6.73 \mathrm{mg} \mathrm{CaCO}_{3} / \mathrm{l}$ ), respectively. According to Lawson (1995), the normal range for fresh-water culture system is (5 to $500 \mathrm{mg} / \mathrm{l}$ ). Increased alkalinity levels aid nitrogen uptake by heterotrophs and the nitrification process by chemoautotrophs (Emerenciano et al., 2017). The total suspended solids level in BFTC group was $(117.05 \pm 14.67 \mathrm{mg} / \mathrm{l})$. For normal TSS range, Hargreaves (2013) recommended (200 to $500 \mathrm{mg} / \mathrm{l}$ ) to minimize the risk of parasite infestation and gill obstruction. Floc level in BFTC group was $(6.48 \pm$ $1.01 \mathrm{ml} / \mathrm{l})$. According to Emerenciano et al. (2017), the ideal floc level for the Nile tilapia rearing is (5 to $20 \mathrm{ml} / \mathrm{l}$ ) noting that the higher levels may increase oxygen consumption by BFT bacteria and may cause gill obstruction.

\section{CONCLUSION}

The results of the present study proved that the biofloc system has a strong capacity to protect gills of the Nile tilapia against A. sobria infection. Additionally, in the early stage of $A$. sobria infection, the gills are severely affected, and its injury may not be observed, paving the way for other diseases. Furthermore, the skin may show hyperemia grossly without any histopathological alterations. After infection, biofloc culture water and fish gut are richer in heterotrophic bacterial population indicating its capacity to compete A. sobria infection. Further investigation to demonstrate the changes of microbial community structure of BFT against $A$. sobria is needed. 


\section{REFERENCES}

Abbott, S. L.; Cheung, W. K. W. and Janda, J. M. (2003). The genus Aeromonas: biochemical characteristics, atypical reactions, and phenotypic identification schemes. J. Clin. Microbiol., 41(6): 2348-2357.

Abraham, T. J.; Babu, S.; Mondal, S. and Banerjee, T. (2007). Effects of dietary supplementation of commercial human probiotic and antibiotic on the growth rate and content of intestinal microflora in ornamental fishes. Bangladesh J. Fish. Res., 11(1): 57-63.

Ahmed, S.; Ahmad, M.; Swami, B. L. and Ikram, S. (2016). A review on plants extract mediated synthesis of silver nanoparticles for antimicrobial applications: a green expertise. J. Adv. Res., 7(1): 17-28.

Ajadi, A.; Sabri, M. Y.; Dauda, A. B.; Ina-Salwany, M. Y.; Hasliza, A. H. and Malaysia, P. (2016). Immunoprophylaxis: A Better Alternative Protective Measure against Shrimp Vibriosis-A Review. PJSRR, 2: 2028-2462.

Angeles- Escobar, B. E.; da Silva, S. M. B. C. and Severi, W. (2021). Growth, red blood cells, and gill alterations of red pacu (Piaractus brachypomus) fingerlings by chronic exposure to different total suspended solids in biofloc. J World Aquac Soc. 2021: 1-17. https://doi.org/10.1111/jwas.12837.

American Public Health Association (APHA) (1998). Standard methods for the examination of water and wastewater. Washington, DC.

Austin, B.; Austin, D. A. and Munn, C. B. (2007). Bacterial fish pathogens: disease of farmed and wild fish (Vol. 26). Springer, Dordrecht, The Netherlands, 732pp.

Avnimelech, Y. (2009). Biofloc technology. A Practical Guide Book. The World Aquaculture Society. Baton Rouge, 182pp.

Avnimelech, Y. (2012). Biofloc-based aquaculture systems. Aquaculture Production Systems. New Delhi, India.

Azim, M. E. and Little, D. C. (2008). The biofloc technology (BFT) in indoor tanks: Water quality, biofloc composition, and growth and welfare of Nile tilapia (Oreochromis niloticus). $\quad$ Aquaculture, 283(1-4): 29-35. https://doi.org/10.1016/j.aquaculture.2008.06.036.

Bakhshi, F.; H Najdegerami, E.; Manaffar, R.; Tokmechi, A.; Rahmani Farah, K. and Shalizar Jalali, A. (2018). Growth performance, haematology, antioxidant 
status, immune response and histology of common carp (Cyprinus carpio L.) fed biofloc grown on different carbon sources. Aquac. Res., 49(1): 393-403. https://doi.org/10.1111/are.13469

Bancroft, J. D. and Gamble, M. (2008). Theory and practice of histological techniques. Elsevier health sciences, China.

Bondad-Reantaso, M. G.; Subasinghe, R. P.; Arthur, J. R.; Ogawa, K.; Chinabut, S.; Adlard, R.; Tan, Z. and Shariff, M. (2005). Disease and health management in Asian aquaculture. Vet. Parasitol., 132(3-4): 249-272.

Boyd, C. E. and Tucker, C. S. (2014). Handbook for aquaculture water quality. Auburn Alabama, 439pp.

Boyd, C. E. (1998). Water quality for pond aquaculture. Research and Development Series No.43. In International center for Aquaculture and Aquatic Environments, Alabama Agricultural Experiment Station, Auburn University, Alabama.

Boyd, C. E. (1982). Water quality management for pond fish culture. Elsevier Scientific Publishing Co.,318pp.

Cabello, F. C. (2006). Heavy use of prophylactic antibiotics in aquaculture: a growing problem for human and animal health and for the environment. Environ. Microbiol., 8(7): 1137-1144.

Cai, W.; Li, S. and Ma, J. (2004). Diseases resistance of Nile tilapia (Oreochromis niloticus), blue tilapia (Oreochromis aureus) and their hybrid (female Nile tilapiax male blue tilapia) to Aeromonas sobria. Aquaculture, 229(1-4): 79-87.

Camargo, M. M. P. and Martinez, C. B. R. (2007). Histopathology of gills, kidney and liver of a Neotropical fish caged in an urban stream. Neotrop. Ichthyol., 5(3): 327336.

Chen, I. C. (1988). Aquaculture in Taiwan. Fishing News Book. London, 373pp.

Dar, G. H.; Dar, S. A.; Kamili, A. N.; Chishti, M. Z. and Ahmad, F. (2016). Detection and characterization of potentially pathogenic Aeromonas sobria isolated from fish Hypophthalmichthys molitrix (Cypriniformes: Cyprinidae). Microb. Pathog., 91: 136-140. https://doi.org/10.1016/j.micpath.2015.10.017

Dong, H. T.; Nguyen, V. V.; Le, H. D.; Sangsuriya, P.; Jitrakorn, S.; Saksmerprome, V.; Senapin, S. and Rodkhum, C. (2015). Naturally concurrent infections of bacterial and viral pathogens in disease outbreaks in cultured Nile tilapia (Oreochromis niloticus) farms. Aquaculture, 448: 427-435. 
Ekasari, J.; Azhar, M. H.; Surawidjaja, E. H.; Nuryati, S.; De Schryver, P. and Bossier, P. (2014). Immune response and disease resistance of shrimp fed biofloc grown on different carbon sources. Fish Shellfish Immunol., 41(2): 332-339.

El-Naggar, M.; Salaah, S.; El-Shabaka, H.; Abd El-Rahman, F.; Khalil, M. and Suloma, A. (2021). Efficacy of dietary chitosan and chitosan nanoparticles supplementation on health status of Nile tilapia, Oreochromis niloticus (L.). Aquac. Rep., 19: 100628.

El-Shafiey, M. H. M.; Mabroke, R. S.; Mola, H. R. A.; Hassaan, M. S. and Suloma, A. (2018). Assessing the suitability of different carbon sources for Nile tilapia, Oreochromis niloticus culture in BFT system. AACL Bioflux, 11(3): 782-795.

El Deen, A. E. N.; Dorgham-Sohad, M.; Hassan-Azza, H. M. and Hakim, A. S. (2014). Studies on Aeromonas hydrophila in cultured Oreochromis niloticus at Kafr El Sheikh Governorate, Egypt with reference to histopathological alterations in some vital organs. World J. Fish Mar. Sci., 6(3): 233-240.

Elbehiry, A.; Marzouk, E.; Abdeen, E.; Al-Dubaib, M.; Alsayeqh, A.; Ibrahem, M.; Hamada, M.; Alenzi, A.; Moussa, I. and Hemeg, H. A. (2019). Proteomic characterization and discrimination of Aeromonas species recovered from meat and water samples with a spotlight on the antimicrobial resistance of Aeromonas hydrophila. Microbiologyopen, 8(11): 1-14. https://doi.org/10.1002/mbo3.782

Emerenciano, M. G. C.; Martínez-Córdova, L. R.; Martínez-Porchas, M. and Miranda-Baeza, A. (2017). Biofloc technology (BFT): a tool for water quality management in aquaculture. Water Quality, 5: 92-109.

Emerenciano, M. G. C.; Gaxiola, G. and Cuzon, G. (2013). Biofloc technology (BFT): a review for aquaculture application and animal food industry. Biomass NowCultivation and Utilization, 301-328pp.

FAO. (2020). Sustainability in action. State of World Fisheries and Aquaculture. Rome. https://doi. org/10.4060/ca9229en.

Ferreira, M. G. P.; Melo, F. P.; Lima, J. P. V; Andrade, H. A.; Severi, W. and Correia, E. S. (2017). Bioremediation and biocontrol of commercial probiotic in marine shrimp culture with biofloc. Lat. Am. J. Aquat. Res., 45(1): 167-176.

Fleckenstein, L. J.; Tierney, T. W. and Ray, A. J. (2018). Comparing biofloc, clearwater, and hybrid recirculating nursery systems (Part II): Tilapia (Oreochromis niloticus) production and water quality dynamics. Aquac. Eng., 82: 80-85.

Forouhar Vajargah, M.; Mohamadi Yalsuyi, A.; Hedayati, A. and Faggio, C. (2018). 
Histopathological lesions and toxicity in common carp (Cyprinus carpio L. 1758) induced by copper nanoparticles. Microsc. Res. Tech., 81(7): 724-729.

Haghparast, M. M.; Alishahi, M.; Ghorbanpour, M. and Shahriari, A. (2020). Evaluation of hemato-immunological parameters and stress indicators of common carp (Cyprinus carpio) in different $\mathrm{C} / \mathrm{N}$ ratio of biofloc system. Aquac. Int., 28(6): 2191-2206. https://doi.org/10.1007/s10499-020-00578-1

Hargreaves, J. A. (1998). Nitrogen biogeochemistry of aquaculture ponds. Aquaculture, 166(3-4): 181-212.

Hargreaves, J. A. (2013). Biofloc production systems for aquaculture (Vol. 4503). Southern Regional Aquaculture Center Stoneville, MS, $11 \mathrm{pp}$.

Hepher, B. and Pruginin, Y. (1981). Commercial Fish Farming. A Wiley-Interscience Publication. John Wiley and Sons, New York, USA.

Ibrahim, R. E.; Amer, S. A.; Farroh, K. Y.; Al-Gabri, N. A.; Ahmed, A. I.; ElAraby, D. A. and Ahmed, S. A. A. (2021). The effects of chitosan-vitamin C nanocomposite supplementation on the growth performance, antioxidant status, immune response, and disease resistance of Nile tilapia (Oreochromis niloticus) $\begin{array}{llll}\text { fingerlings. } & \text { Aquaculture, } & 736269 .\end{array}$ https://doi.org/10.1016/j.aquaculture.2020.736269

Jia, Y.; Wang, L.; Qu, Z.; Wang, C. and Yang, Z. (2017). Effects on heavy metal accumulation in freshwater fishes: species, tissues, and sizes. Environ. Sci. Pollut. Res., 24(10): 9379-9386.

Kim, D.; Brunt, J. and Austin, B. (2007). Microbial diversity of intestinal contents and mucus in rainbow trout (Oncorhynchus mykiss). J. Appl. Microbiol., 102(6): 1654 1664.

Kim, S.; Pang, Z.; Seo, H.; Cho, Y.; Samocha, T. and Jang, I. (2014). Effect of bioflocs on growth and immune activity of Pacific white shrimp, Litopenaeus vannamei postlarvae. Aquac. Res., 45(2): 362-371.

Kishawy, A. T. Y.; Sewid, A. H.; Nada, H. S.; Kamel, M. A.; El-Mandrawy, S. A. M.; Abdelhakim, T. M. N.; El-Murr, A. E. I.; Nahhas, N. El; Hozzein, W. N. and Ibrahim, D. (2020). Mannanoligosaccharides as a carbon source in biofloc boost dietary plant protein and water quality, growth, immunity and aeromonas hydrophila resistance in nile tilapia (Oreochromis niloticus). Animals, 10(10): 1-24. https://doi.org/10.3390/ani10101724

Kozińska, A. (2007). Dominant pathogenic species of mesophilic aeromonads isolated 
from diseased and healthy fish cultured in Poland. J. Fish Dis., 30(5): 293-301

Lawson, T. B. (1995). Flow Estimation and Measurement. In Fundamentals of Aquacultural Engineering. Springer, Boston, 133-156pp.

Li, Y. and Cai, S. H. (2011). Identification and pathogenicity of Aeromonas sobria on Tail-rot disease in Juvenile Tilapia Oreochromis niloticus. Curr. Microbiol., 62(2): 623-627. https://doi.org/10.1007/s00284-010-9753-8

Mabroke, R. S.; El-Husseiny, O. M.; Zidan, A. E.-N. F. A.; Tahoun, A.-A. and Suloma, A. (2019). Floc meal as potential substitute for soybean meal in tilapia diets under biofloc system conditions. J. Oceanol. Limnol., 37(1): 313-320.

Mastan, S. A. (2015). Use of immunostimulants in aquaculture disease management. Int. j. fish. aquat. sci., 2(4): 277-280.

Menaga, M.; Felix, S.; Charulatha, M.; Gopalakannan, A. and Panigrahi, A. (2019). Effect of in-situ and ex-situ biofloc on immune response of Genetically Improved Farmed Tilapia. Fish Shellfish Immunol., 92: 698-705.

Monfort, P. and Baleux, B. (1990). Dynamics of Aeromonas hydrophila, Aeromonas sobria, and Aeromonas caviae in a sewage treatment pond. Appl. Environ. Microbiol., 56(7): 1999-2006.

Mumford, S.; Heidel, J.; Smith, C.; Morrison, J.; MacConnell, B. and Blazer, V. (2007). Fish histology and histopathology. US Fish and Wildlife National Conservation Training Center, Amerika Serikat.

Moustafa, E. M.; Dawood, M. A.; Assar, D. H.; Omar, A. A.; Elbialy, Z. I.; Farrag, F. A. and Zayed, M. M. (2020). Modulatory effects of fenugreek seeds powder on the histopathology, oxidative status, and immune related gene expression in Nile tilapia (Oreochromis niloticus) infected with Aeromonas hydrophila. Aquaculture, 515: 734589.

Najdegerami, E. H.; Bakhshi, F.; Tokmechi, A.; Shiri Harzevili, A.; Sorgeloos, P. and Bossier, P. (2017). Dietary effects of poly- $\beta$ - hydroxybutyrate on the growth performance, digestive enzyme activity, body composition, mineral uptake and bacterial challenge of rainbow trout fry (Oncorhynchus mykiss). Aquac. Nutr., 23(2): 246-254.

Noga, E. J. (2010). Fish disease: diagnosis and treatment. John Wiley \& Sons, North Carolina, 520pp.

Pérez-Fuentes, J. A.; Pérez-Rostro, C. I.; Hernández-Vergara, M. P. and MonroyDosta, M. del C. (2018). Variation of the bacterial composition of biofloc and the 
intestine of Nile tilapia Oreochromis niloticus, cultivated using biofloc technology, supplied different feed rations. Aquac. Res., 49(11): 3658-3668.

Ray, A. J.; Dillon, K. S. and Lotz, J. M. (2011). Water quality dynamics and shrimp (Litopenaeus vannamei) production in intensive, mesohaline culture systems with two levels of biofloc management. Aquac. Eng., 45(3): 127-136.

Ray, A. J.; Drury, T. H. and Cecil, A. (2017). Comparing clear-water RAS and biofloc systems: Shrimp (Litopenaeus vannamei) production, water quality, and biofloc nutritional contributions estimated using stable isotopes. Aquac. Eng., 77: 9-14.

Reda, R. M.; Mahmoud, R.; Selim, K. M. and El-Araby, I. E. (2016). Effects of dietary acidifiers on growth, hematology, immune response and disease resistance of Nile tilapia, Oreochromis niloticus. Fish Shellfish Immunol., 50: 255-262. https://doi.org/10.1016/j.fsi.2016.01.040

Robles-Porchas, G. R.; Gollas-Galván, T.; Martínez-Porchas, M.; MartínezCordova, L. R.; Miranda-Baeza, A. and Vargas-Albores, F. (2020). The nitrification process for nitrogen removal in biofloc system aquaculture. Rev Aquac., 12(4): 2228-2249. https://doi.org/10.1111/raq.12431

Romano, N.; Dauda, A. B.; Ikhsan, N.; Karim, M. and Kamarudin, M. S. (2018). Fermenting rice bran as a carbon source for biofloc technology improved the water quality, growth, feeding efficiencies, and biochemical composition of African catfish Clarias gariepinus juveniles. Aquac. Res., 49(12): 3691-3701.

Sakai, M. (1999). Current research status of fish immunostimulants. Aquaculture, 172(12): 63-92.

Samocha, T. M. (2019). Sustainable biofloc systems for marine shrimp. Academic Press.463pp.

Stahlke, E. V. R.; Rossa, L. S.; Silva, G. M.; Sotomaior, C. S.; Pereira, A. J.; Luciano, F. B. and MACEDO, R. E. F. D. (2018). Effects of modified atmosphere packaging (MAP) and slaughter age on the shelf life of lamb meat. Food Sci. Technol., 39: 328-335.

Sutton, S. (2011). Accuracy of plate counts. J. Valid. Technol., 17(3): 42-46.

Toranzo, A. E.; Baya, A. M.; Romalde, J. L. and Hetrick, F. M. (1989). Association of Aeromonas sobria with mortalities of adult gizzard shad, Dorosoma cepedianum Lesueur. J. Fish Dis., 12(5): 439-448.

Trust, T. J. (1986). Pathogenesis of infectious diseases of fish. Annu. Rev. Microbiol., 40(1): 479-502. 
Weston, D. P. (1996). Environmental considerations in the use of antibacterial drugs in aquaculture. Blackwell Science, Oxford.

World Health Organization. (1999). Food safety issues associated with products from aquaculture: report of a joint FAO/NACA/WHO study group (Vol. 883). Geneva.

Yildirim, M. Z.; Benlı, A. Ç. K.; Selvı, M.; Özkul, A.; Erkoç, F. and Koçak, O. (2006). Acute toxicity, behavioral changes, and histopathological effects of deltamethrin on tissues (gills, liver, brain, spleen, kidney, muscle, skin) of Nile tilapia (Oreochromis niloticus L.) fingerlings. Res. J. Environ. Toxicol., 21(6): 614-620.

Yu, J. H.; Han, J. J.; Kim, H. J.; Kang, S. G. and Park, S. W. (2010). First report of Aeromonas veronii infection in farmed Israeli carp Cyprinus carpio in Korea. Fish Pathol., 23(2): 165-176. 